\title{
Enclaving:
}

\section{Spatial Detachment as an Aesthetics of Imagination in an urban sub-Saharan African context}

\author{
Morten Nielsen, Jason Sumich \& Bjørn Enge Bertelsen ${ }^{1}$
}

\section{Morten Nielsen}

National Museum of Denmark

Ny Vestergade 10

DK-1471 Copenhagen K

Phone: +45 28562332 (mobile)

Email: morten.nielsen@natmus.dk

https://orcid.org/0000-0002-6165-0360

Author bio:

Morten Nielsen is a social anthropologist and currently a senior researcher at the National Museum of Denmark and head of 'Middle Class Urbanism', an interdisciplinary research project focusing on middle class urbanism in the global south. A key focus for his research is the intersection between time and materiality. Based on extended ethnographic research in Latin America, sub-Saharan Africa, UK and USA, he has published on such issues as urban development, urban and national citizenship, urban politics, access to urban land, state formation, formal/informal governance, vernacular architecture, materiality, time and temporality, human creativity, comedy and political cosmologies.

\footnotetext{
${ }^{1}$ The three authors are currently involved in two interconnected research projects, which examine the socio-cultural, economic and political ramifications of enclaving in sub-Saharan African cities: 'Middle Class Urbanism. An interdisciplinary study of the physical reordering of urban sub-Saharan Africa' (https://projects.au.dk/middleclassurbanism) funded by the Independent Research Fund Denmark and 'Urban Enclaving Futures' (https://www.uib.no/en/urbanenclavingfutures) funded by the Norwegian Research Council. The three authors have contributed equally to this article.
} 


\section{Jason Sumich}

Department of Sociology

University of Essex

Wivenhoe Park

CO4 3SQ

United Kingdom

Email: js18415@essex.ac.uk

Author bio:

Jason Sumich is a Lecturer at the Department of Sociology, University of Essex. He is a political anthropologist who works on issues of class formation, post-socialism, the state, hegemony, citizenship, urban inequality and the politics of enclaving in southern Africa, primarily Mozambique. his current research explores emerging forms of urban governance and control and he is a member of the project "Enclaving: Patterns of Global Futures in Three African Cities" funded by the Norwegian Research Council. His recent monograph is entitled The Middle Class in Mozambique: The State and the Politics of Transformation in Southern Africa, was published by Cambridge University Press in 2018.

\section{Bjørn Enge Bertelsen}

Department of social anthropology

University of Bergen

Fosswinckelsgate 6

5020 Bergen

Phone: +47 41103883 (mobile)

Email: Bjorn.Bertelsen@uib.no

https://orcid.org/0000-0002-3194-3664

Author bio:

Bjørn Enge Bertelsen is a professor in the Department of Social Anthropology, University of Bergen and heads the research project "Enclaving: Patterns of global futures in three African cities". Political anthropology, egalitarianism, cosmology and urban Africa are among his research 
interests and recent books include the monograph Violent Becomings: State Formation, Sociality, and Power in Mozambique (2016) and the edited works Crisis of the State: War and Social Upheaval (with Bruce Kapferer, 2012); Violent Reverberations: Global Modalities of Trauma (with Vigdis Broch-Due, 2016); Critical Anthropological Engagements in Human Alterity and Difference (with Synnøve Bendixsen, 2016) and Mozambique on the Move. Challenges and Reflections (with Sheila Pereira Khan and Maria Paula Meneses, 2019). 


\begin{abstract}
While detachment and separation continue to be central to urban development across the globe, in several sub-Saharan African cities it has acquired a particular form of acute social and political efficacy. In many European and American cities, the making of fortified enclosures is considered as an effect of an endemic fear of societal dissolution and a growing number of sub-Saharan African cities are, seemingly, affected by a similar socio-political and economic dynamic. However, in subSaharan Africa the spatial lines of separation that isolate the affluent few from surrounding urban spaces follow both a much wider and less coordinated meshwork of social divisions and political fissures and draws on a deeper socio-cultural, economic and historical repertoire. In this article we trace the contours of enclaving as a critical urban driver, which is rapidly changing the social and physical fabric of cities across the sub-Saharan continent. Rather than considering enclaving simply as a physical manifestation of dominance and privilege, however, we consider it as an 'aesthetics of imagination' that migrates through the cities and thereby weaves together otherwise dissimilar and distinct social practices, spaces and political desires and economic aspirations.
\end{abstract}

\title{
Keywords
}

Enclaving, migrating spaces, aesthetics of imagination, sub-Saharan Africa, Mozambique, Maputo, urban development, urban theory 


\section{Introduction}

Something peculiar is happening in cities across sub-Saharan Africa: Without political coordination and lacking overall synchronization of collective and governmental strategies, cities are beginning to move at similar socio-economic velocities as if prompted by the same 'urban engine'. Seemingly disparate modalities of social life reflect analogous urban aesthetics and spatial affects and are increasingly structured around comparable forms of socio-physical detachment and separation. While the sub-Saharan region contains diverse and often contradictory historical genealogies, many urban environments have become an interwoven patchwork of spaces and relations, fissures and tensions, which pulsate with similar or at least analogue rhythms (see also Simone 2019). This insistent urban drive derives its awkward but insistent regularity by entrenching a delimited set of political, cultural and economic forms of difference around similar forms of spatial aesthetics. At the outset, we define this peculiar urban drive as 'enclaving'. Enclaving, we will argue, is a generative and transformative cultural orientation regarding the relationship between urban social life and the city's built environment based on a notion of spatial detachment by which social actors engage with and co-produce the urban order.

More than 25 years ago, the American architecture critic Michael Sorkin (1992) described an emerging form of fragmented cityscape, whose anchorage in physical spaces was gradually becoming unmoored. This particular urban form was characterized by 'new modes of segregation' with city management having 'largely ceased its historic role as the integrator of communities in favor of managing selective development and enforcing distinction' (1992: xiii-xiv). As a neoliberal refraction of the 'postmetropolis' (Soja, 2000), the cityscape, whose dynamics Sorkin was so succinctly capturing, could be found across Euro-America. With a flexible governmental aesthetics of security and minute technologies of surveillance, it was driven by the need to liberate the fortunate few from the everyday chaos that characterized the lives of the many (Caldeira, 2001; MacKenzie, 1994). According to Harvey (2000: 152), the effect was to,

...divide up the urban realm into a patchwork quilt of islands of relative affluence struggling to secure themselves in a sea of spreading squalor and decay. The overall effect is division and fragmentation of the metropolitan space, a loss of sociality across diversity, and a 
localized defensive posture towards the rest of the city that becomes politically fractious if not downright dysfunctional.

Since then, a growing number of Euro-American cities, such as Los Angeles (USA), London (UK), and Berlin (Germany), are being constituted by 'patchwork quilts' of utopian and dystopian spaces. This development seems to eclipse the historical genealogies of local formations of property rights and procedures for accessing land, that Cirolia has aptly defined as the 'entrenched legacies' of their physical locations (2013). Rather than integration within the existing socio-physical fabric, the starting point for acting upon and within the city is isolation from that which is considered socially inferior and therefore also potentially dangerous (cf. Caldeira, 1996). Furthermore, as Paul L. Knox asserts in an incisive critique of what he terms the 'schlock-and-awe urbanism' of the US, an increasingly prominent aspect of this trend is 'the secession of the successful' into both masterplanned communities with a concomitant retreat into securitized 'lifestyle enclaves' (Knox, 2008: 57-65). There has been, as also Davis bleakly noted, a 'conscious "hardening" of the city surface' (1992: 232) against the poor and dispossessed in the attempt to make public facilities and spaces as uninhabitable as possible, concomitant with the rise of 'defensive architecture' expelling the undesirables from urban spaces (Smith and Walters, 2018). At the same time, the affluent elites have increasingly retreated to fortified enclaves governed by property values where power rested on the capacity to dominate and govern access to space (MacKenzie, 1994: 177).

When considered from a distance, a growing number of urban landscapes across the sub-Saharan African region seems to reverberate with similar tensions of power, utopian drives and architectural affects as those of Euro-American cities mentioned above. In seeking to fast-forward into a future unhindered by the past, urban developers (architects, corporate conglomerates, planners and real estate agents) and city and national governments have become enthralled by the idea of creating self-sufficient island-like enclosures inside or at the margins of existing sub-Saharan African cities. During recent decades, cities such as Dar-es-Salaam (Tanzania), Kinshasa (DR Congo), Pretoria (South Africa) and Nairobi (Kenya) have thus been 'reurbanized' (Murray, 2013) to serve the interests of both local and foreign property-holding elites. In some respects not unlike the situation in urban Europe and the USA, these recent city-making projects are driven by the ambition of creating entirely new cities 'out of whole cloth rather than rehabilitating the existing built environment' (op.cit.:1). In doing so, entrepreneurial investors and urban developers bypass the 
unregulated chaos of existing and poorly functioning urban environments and allow the fortunate few to retreat to insular enclaves with efficient infrastructure, up-to-date services, and a comprehensive system of security based on surveillance and restricted access.

However, despite such apparent similarities with Euro-American cities, something else is unfolding in many urban areas across sub-Saharan Africa. For, in Euro-America, the making of fortified enclaves has been predominantly described as a socio-economic effect of what Davis has called an endemic 'ecology of fear' (1998). Growing from doubts that the regulatory systems of the 'old liberal paradigm' is no longer in force, a new 'post-liberal' elite has closed itself off in secluded 'privatopias' (MacKenzie, 1994) — an enclave form that caters to consumerism, residence and/or production (see also Sidaway, 2007). In sub-Saharan Africa, by contrast, the spatial lines of separation that isolate the affluent few from surrounding urban spaces follow a much wider and less coordinated meshwork of social divisions and political fissures and with deeper socio-cultural, economic and historical underpinnings. While sub-Saharan African cities are saturated with spatial imageries and aspirations of ever more monumental urban development projects, the volatile relationship between ideal and realization is maintained by an ill-coordinated arrangement of actors and agendas, whose priorities and strategies only rarely lead to the expected outcome (Boeck 2011; Murray 2017). Spatial imageries of enclave urbanism circulate between different sites and among multiple actors - real estate agents, financial investors, conglomerates of local and foreign construction companies, governmental collaborators - and it is their ongoing contestation and negotiation rather than their eventual but frequently unlikely realization that give to the city the particular social efficacy, affective allure and aspirational drive that we wish to capture by the notion of 'enclaving'. We will therefore suggest to consider enclaving as an 'aesthetics of imagination'; that is, as an aesthetic conduit for new urban imaginaries based on the idea of the materially segregated spatial unit (cf. Cinar \& Bender 2007; Nielsen \& Pedersen 2015). Whereas these spatial imageries may be sedimented in the physicality of the city, their social drive arises primarily from the way that they are capable of migrating or circulating across different urban landscapes (Ong 2011) and thereby stitch together otherwise disparate social practices, localities, political visions and economic aspirations.

In the following, we want to trace the contours of this phenomenon, which is rapidly changing the social and physical fabric of cities across the sub-Saharan region. We begin by charting the 
historical genealogy of the enclave as physical form and utopian desire that informs a discussion of a number of present-day examples. After an empirical interlude, where we provide concrete examples of enclaving from one sub-Saharan African city (Maputo, the capital of Mozambique), we end with an extended discussion of enclaving as both an analytical concept and an empirical phenomenon.

\section{Antecedents: Utopia, separation and contagion}

When delving into the conceptual, historical and philosophical genealogy of urban enclaving, one is struck by how notions of the city, utopian as well as non-utopian, relate to the core notion of the polis. For, the very notion of the polis depended on the fundamental value of apartness that was elaborated on multiple levels—what Agamben (2015) refers to as the notion of the 'pure city' within Greek classical thought and which, by default, presupposes an outside. Precisely such a separation of a pure inside and impure outside fueled also the notion of classical utopias. As the famed cartographers Georg Braun and Franz Hogenberg demonstrate in 363 beautifully detailed and meticulously rendered images of the world's most renowned cities half a millennium ago, the division between the city and its outside is fundamental to all depictions of a vast array of urban settings (Braun, Hogenberg, and Füssel, 2015 [1572-1617]): Here we find classic enwalled cities, cities encompassed by bodies water and accessible only by bridges or cities nestled atop mountains. These visions reveal the urban as a universal imaginary and representative space presupposing an allocation to the exterior of that which is indigestible for the body of the city: a multilevel instantiation of an idea and aesthetics of separation but one where the inside always had a dynamic relation to the outside (cf. Strathern, 2000). The importance of separation and its necessary outside(s) is driven home precisely by the many and lush illustrations of executions, killings and punishments of adulterers, thieves, pagans, witches etc. at the margins of or outside the city limits, that is, outside the enclave.

Such an encompassment of the polis (or society of the urban), is also the impression conveyed by Balasopoulos' thorough analysis (2014a, 2014b, 2013) of European utopian urban formations, showing that historical notions derive from Platonian discussions of the ideal republic and until the 
neology of the 'New World' coined by Thomas More in $1516 .{ }^{2}$ All revolve, according to Balasopoulos, around a philosophical speculation concerning the 'ideal': the ideal commonwealth, the ideal city, the ideal government and, with time, often rendering a distinction between an 'old' (European) and a 'new' (American, Atlantic) world. Furthermore, in these speculations-highly influential on cosmologies of urban life, citizenship and form-utopia was a New Atlantis (Bacon, 1627; Price, 2016 [2002]), an Oceana (Harrington, 1656) or a theocratic City of the Sun (Campanella, 1981 [1623]). Centuries later, it would become the natural setting of Walden (Thoreau, 1854; Thoreau, 1992 [1910]) or, much more influential, the modernist architectural design of Brasília that exemplify the imaginative force of urban planning projecting an ideal apart (Holston, 1989) — a perfect polis, a perfect enclave_-an argument also made by David Harvey (2010) associating utopia with the urban form. As Blanes and Maskens write (2018: xx) in a recent overview of utopian thought and orientation, 'this projection [of imagination] has produced a history of architectural and urban planning successes and failures, revealing both the intellectual ambition towards the possibility of wellbeing or living well, and the inscription, the physical work oriented towards that same ambition.'

The impulse to purify, egalitarianize and, perhaps, insularize within the context of a polis/citythus mobilizing the force of (utopian) imagination in order to revolutionize and separate the $u r b$ from cosmos and its multitudes-was also given a new impetus with modernist thinkers and architects and their global canvas. As Le Corbusier, an architect with also a world-wide impact, famously stated in his attack on tradition - that 'stifling accumulation of age-long detritus'insisting that architectural form should be liberated from immediate needs of the human (1986 [1931]: 288f):

Society is filled with a violent desire for something which it may obtain or may not. Everything lies in that: everything depends on the effort made and the attention paid to these alarming symptoms.

Architecture or Revolution.

Revolution can be avoided.

\footnotetext{
${ }^{2}$ While we initially limit ourselves here to the trajectory of Western connectivities between utopia and the city, there are, surely, arguments to be made for exploring such dimensions elsewhere-as Zhao (2006) has done for the imperial history of (pre-revolutionary) China or as has been explored more broadly by, for instance, Seligman (1989).
} 
However, as also the early European and Western utopian visions of the city showed, also more recently, manoeuvring in an urban space to preclude encountering the other has not always been the desire to generate the enclave form-a mold that is in itself plural, fuzzy and plastic. A case in point here is how what one could call a 'softer form' of distinguishing between inside and outside was integral to a European modernist tradition of architecture, urban planning and pro-social (and sometimes Socialist) vision of society, space and relationality. Concretely, in modernist European architecture this manifested, for instance, as a tendency to attempt to create living spaces which were miniature (and, thus, idealized and utopian) cities - the enclave structure within the city as an idealized form (Delft architectural studies on housing DASH, 2011; see also Graham, 2016: 220ff). This particular aesthetic imagination of the enclave, often guided by the idea of modeling the city on the house, varied greatly in size and the spaces they were to be constructed; from large-scale urban development on the city's fringes to inner-city urban renewal of several blocks. For instance, as part of such playful engagement with the fundamentals of the city-infrastructure, domicile, workspace - from the end of the 1950s, Dutch architects like Piet Blom drew heavy inspiration from orientalist views of the Casbah when re-thinking the future urban landscape (van den Heuvel, 2011). Furthermore, such inspiration from an enclaved and exotic elsewhere-an appropriation and domestication of the orientalist vision of harmonious secluded living — also translated into a largescale flexible, organic superstructure of the enclave form, the Noah's Ark project: 'It entailed a large-scale urbanization scheme for the Amsterdam region by way of a vast system of interlocking grid structures of massive, polycentric units each capable of housing 10,000 to 15,000 inhabitants' (van den Heuvel, 2011: 61). And the point is, of course, exactly the pliability and non-fixity of these structures as these were imagined: The polycentric ideal already indicates that one unit or material form may replace or interlock with the other. This involves not only endless possibilities of replicability and appropriability through spaces but also pathways for the migration of the form through and interconnecting (open-ended or opened) households. An aesthetic of separation as a material form paradoxically, therefore, reverberates through the urban fabric; the material form migrating (or radiating, but unevenly) outwards.

Having traced some aspects of utopian and ideal cities through would-be revolutionary architectural and other interventions, it is worthwhile to briefly look at classical conceptual distinctions within urban studies, namely that between 'urbanization' and 'city' and how it relates to enclaving. As Robert Exo Adams (2014) argues, this distinction is not only a claim of differences in built form or 
spatialities but rather reveals a temporal trajectory which suggests that "there was a period of time in which spatial entities called 'cities' existed, grew, shrank, were sacked, constructed from scratch and left in ruins, but never urbanised as such; likewise, that there is a time after which cities had been supplanted by an entirely different spatial order which we can call the 'urban'." Thinking with Adams's analytic optic - which further emphasises that the urban implies a number of political dispositions - presents us with an organism-like urbanization understood as oriented towards, precisely, the co-production of articulations of both interconnectedness and separation premised, crucially, on circulation.

Taking in Adams's crucial reading of the global urban, enclaving is the product not necessarily of processes of strict separation or fervent purification (as in a Le Corbuserian revolution): Instead, what Adam's reading alerts us to see the urban as always already emergent and mobile and, therefore, also an aesthetics circulating across and between spaces. Arguably, such developments have, as we have indicated above and as we will further detail below, assumed particular importance in sub-Saharan Africa where the urban landscape is not a repository of pure, stable and unadulterated hope but as replete with mutating, situated and ephemeral forms of possibility - a heterotopian space that is impure and multiple, as in de Boeck's and Plissart's rendition of Kinshasa (2014 [2004]: xviii). Analyzing spaces such as cemeteries, theatres, gardens and museums, de Boeck and Plissart hold that these are heterochronic, that are nowhere or elsewhere-'spaces that are marked by specific systems of opening and closing, or that create room for illusion or compensation' (2014 [2004]: 254). Drawing on Kinshasa's shifting character, de Boeck and Plissart argue these urban spaces are generating fleeting possibilities of political and socio-economic opportunity rather than offering the shining totality of utopia as a full ideological or cosmological vision. It is also precisely this dynamic of multiplicity, ephemerality and impurity which has been argued by Quayson (2014) for Accra, namely that the relation between the African city and the utopic is irreducible to a notion of pure creation. This setting apart in an impure manner, as Simone has argued (2019) to be the case for global Southern urban areas, opens up for seeing traces of imaginary and material enclaves reverberating across domains-as a form that may or may not come into fruition - rather than having one's analytical gaze fixed solely on material enclosures. 
Precisely this setting apart in an impure manner and its implications for enclaves is held forth by Heer (2019) in her recent analysis of the interconnected nature of urbanity in Johannesburg and Maputo. She writes that for both cities, 'walls have come to symbolise the vexed conviviality of urban elites and less affluent groups' (2019: 10) and, further, holds that there are many forms of entanglement between spaces, groups of people that characterize these two cities. A similar argument is made by Morton's recent thorough analysis of the racialized colonial forms of aesthetics allocated, often violently, to territories and colonial subjects. He shows, however, that contrary to the stasis sought produced by the colonial masters, aesthetic ideals did traverse erstwhile enclaves and domains.

Although not oblivious to the global construction of fortified enclaves (Caldeira 1999; Schuermans 2016) and the increasingly militarized and securitized urban orders (Ssorin-Chaikov 2018; Glück 2017; Buxton and Hayes 2016), we agree with both Morton's and Heer's thorough analysis of the cases of Johannesburg and Maputo that there is a particular intensity, motility and incompleteness to the circulation of enclaving as an aesthetics of imagination in the sub-Saharan African regionperhaps also reflective of the particularities of wider southern urbanism (see, e.g., Simone and Pieterse, 2017; Kuldova and Varghese, 2017).

\section{Enclaving and contemporary urban models}

In many ways contemporary processes of enclaving, the world over, appear as an ad hoc gesture of despair, the spatial equivalent of closing one's eyes to the problems of urban inequality, as in Schuermans' analysis (2016). Perhaps, that is why the enclave has found few defenders, unlike previous forms of urbanism, such as Jane Jacobs, Ernest Hemingway, Langston Hughes, or Graham Ellis willing to wax lyrical about the scruffy charm and cultural verve of the Left bank in Paris, Brooklyn or Harlem in New York or District Six in Cape Town to name but a few. Mike Davis has described enclaved communities as a new form of class war whose medium is the built environment (1992: 228, see also Murray, 2011 for Johannesburg). While many scholars trace the origins of enclaved communities as part of the more extreme and exclusionary trends in contemporary capitalism, as argued in the last section, it may also be important to recognize, for better or worse, the utopic qualities in the rise of gated communities. For instance, the globe spanning conformity of design, which has caused such dismay among urban scholars (examples include Davis 1992; Low 2003, Murray 2011), also betrays elements of utopian ambition. In her masterful survey of utopic 
urban forms, Ruth Eaton found that utopias, '... are presented as absolute solutions, panaceae applicable worldwide and indifferent to factors of local context whether historical, geographical, cultural or other' (2002: 16f). Even the more exclusionary aspects once again have elements of utopic thinking. According to Eaton strict spatial segregation is a common feature for urban utopias throughout the ages; 'Insular and, indeed, often xenophobic, they are protected symbolically and physically from pernicious outside influences either by natural barriers, such as stretches of water or mountain ranges, or by man-made fortifications or greenbelts' (ibid: 17). Much has been written about the rise of gated communities in southern Africa and how this builds on a long legacy of colonial projects for urban segregation and social cleansing (for just some examples see Bunkenborg, M., M. Nielsen, et al, In Press; Ferguson, 2005; Morton, 2019; Murray 2011, 2013, 2015, 2017). We will focus on some of these issues more specifically later in the article, however in this section we want to place this development as part of a wider urban transformation, one firmly situated in the local context while, simultaneously, being deeply influenced by global currents.

Although enclaves may well be the material face of our cruel and heartless economic system, they can also be seen as migrating material forms through which to transform the urban fabric that is simultaneously both exclusionary and utopic. As David Harvey famously observed, the spatial organization of a city tends to shape the social processes that take place within it (1973: 27). For many urban analysts, enclaved communities are dangerous precisely because they are symptomatic of larger neo-liberal processes by splintering and fragmenting the city, privatizing public space, and undermining social diversity and meaningful citizenship as elite segments siphon off scarce resources and retreat behind well-fortified walls (Blakely and Snyder, 1997; Davis, 1992; Graham and Martin, 2011; Low, 2003; Murray, 2011). There is much to commend this critique, as it paints a depressingly accurate picture of how life in urban areas is being transformed through neo-liberal practices of governance.

However accurate elements of this critique may be, it is misleading to reduce enclaving to just a salvo of neo-liberalism's global assault rendered in concrete. Pow, drawing on the work of Jacobs, argues that even seemingly global forms of urban design, be they skyscrapers or gated communities, are always situated in their specific context (2009: 215). In Pow's analysis of Singapore, the growing use of enclaved communities by the middle class takes place in a context where the state already presides over the widespread provision of public housing, rather than a 
result of weak or excessively permissive planning strategies as usually assumed. The Singaporean state views the provision of enclaved communities as part of its wider overall housing strategy, which is geared more specifically towards reproducing state legitimacy among a middle class, while maintaining an officially mandated ethnic balance. As mentioned earlier, such efforts combine a wide variety of forms and social practices, state mandated efforts at social engineering, real estate speculation, exclusion and the carving out of one's own territory into an overarching urban drive. Although this drive in Asia and beyond, is commonly referred to as neo-liberalism, these seemingly 'hybrid' practices of housing provision, which blend capitalist elements alongside different, often more statist political techniques also appear to be common in the Peoples' Republic of China, where enclaved communities are, perhaps, the dominant urban form. Zhang demonstrates how the construction, management and marketing of enclaved communities in the PRC are characterized by hybridity (2010). Not only are many state-owned corporations involved, blurring the lines between capitalist and socialist, but state-owned companies adopt capitalist practices from corporate models in places like Taiwan, Japan, Germany, while private Chinese corporations adopt the organization structure and ethos of the Chinese communist party (ibid).

Additionally, enclaved communities in East Asia tend to take on different social connotations and are often popularly viewed either as positive or with ambivalence (Breitung, 2012; Pow, 2009; Wissink et al. 2012, Zhang 2010). To some degree, this stems from the history of urban design in places like China, where walled compounds have long been the norm, even during the Maoist period. Many analysts who focus on Latin America, South Africa and the United States have decried the ways in which enclaved communities attack the social diversity, something that they think should characterize urban life, even as such areas have long been predicated by intense forms of segregation. However, in China, walls and gates are proposed as the solution to the problem of social diversity (Breitung; 2012: 283; see also again Zhang, 2010). For Breitung, security in China is not just being free of crime, but also is predicated on '...clearly marked social structures, stability and homogeneity...' (2012: 285). After the political upheavals and enforced communalism of the Maoist period, enclaved communities are an oasis that keeps the complex, ever changing and threatening world at bay (Breitung 2012; Zhang 2010). Moreover, such a vision is also reflected by a solid support for building enclaved structures by Chinese urban planners, as recently shown (Liao et al. 2019). These dynamics provide a modicum of stability even while the materiality of enclaved 
communities reshapes class relations and creates new forms of exclusion, a politics of detachment that do not simply reflect society but also transforms it.

In sum, all the above examples - from early utopian and philosophical speculation through what could be labelled a time of modernist utopia globally in in the 1950s and 1960s, on the one hand, to the multiplex, open-ended assemblage form of the current city - underline that enclaving is a longstanding yet unstable phenomenon of human orientation. This implies that its utopic engine and orientation should not be relegated to the margins of the process of generating urban forms-or visions thereof: As this cursory overview of some features of the shifting registers of tropes of separation has shown, the enclave form, hard or soft, material and immaterial, assemblage or pure, is making a permanent yet dynamic impact on various strands of urban history and contemporary urban practice and orientation: As a spatial and material form that migrates across veritable urban orders and the imagination of men, it is intensely present in the multiscalar and multidomain articulation and generation of urban models and their realities.

\section{An empirical interlude: The reverberations of enclaving in one sub-Saharan}

\section{African city}

As we have previously argued, enclaving is Janus faced. It can be seen as the embodiment of soulless consumerism, as argued by so many urban scholars. However, the endless churning out of a conformist model of urban living also has deep, often generative or even utopic roots. In Thomas More's utopia, urban design was described as a, '...series of clone-like towns. It is one of the most alarming features of Utopia for it suggests the relentless domination of a single model - the brainchild, in this case, of Utopus - across a territory. It thus appears to vindicate the aspirations to uniform global domination that is to characterize later utopian schemes' (Eaton, 2002: 67). The desire for uniformity and the erasure of difference within a set spatial form has been a common feature of both utopic and dystopic thinking. It is a combination of utopic and dystopic aspects, creativity and conformity, aspiration and exclusion, security and fear that have made enclaving such a powerful migratory space and material form. It is powerful enough to reshape the urban environment wherever it is found, while being flexible enough to be shaped by local concerns and cleavages. 
Before moving on, we will trace these migrating spaces and material forms to demonstrate how enclaving both shapes and is, in turn, reshaped in a specific context. Although such a discussion could conceivably take place in any major city in sub-Saharan Africa, we will focus on Maputo, the capital of Mozambique. This is due to the fact that all three authors have long experience working in Maputo and its surrounding areas and because it is a veritable repository of instances of enclaving understood as an aesthetics of imagination that circulates, unmoored and with the capacity to alter horizons and practices, in very different domains. Let us be specific:

\section{Vignette 1: A war of walls}

Maxaquene is a Maputo neighborhood that is both quite poor and centrally located, now generally viewed as undergoing rampant gentrification. At the physical and visible level, such gentrification involves large tracts of land being transformed into middle-class housing, apartment blocks or gated communities, especially in the areas that are close to the main roadways. So far, this reflects global forms of gentrification (Lees et al., 2016). The immediately tangible and physical effects, however, does not necessarily conform to global templates of gentrification and reveal instead an aesthetic imaginary where the material form takes on particular characteristics. For instance, the mushrooming of small-scale condominiums that perforate the hitherto one-floor (or rarely two) houses that comprise the urban landscape of Maxaquene: Now, glass, steel and concrete structures are sprouting through the red soil, changing the physical outlook of the area as well as, importantly, the cosmologies and horizons of what urban life and the city is (see also Bertelsen et al., 2014). Not only indicating the well-known turn to verticality (see Graham 2016), the form also breaks with the single-story landscape of tight-knit households that have comprised part and part of both colonial and postcolonial urban development in Maputo (see Morton 2018). For Author 3, this re-orientation has therefore become very prominent in recurring conversations he has had with Maxaquene inhabitants about the nature of the neighborhood, its materialities and urban and domestic spacesuch as in this conversation in January 2019 with an elderly man whom we may call 'Bernardo'. Born in 1956, Bernardo moved to the then open, largely rural space of Maxaquene in 1971 and worked as a janitor, domestic worker and then a tobacco worker until losing his last job in 2013. When author 3 asked him about changes to his small plot and Maxaquene, he recollected: 
Before 1982, I lived in a house with my brother. In 1982, I got my own plot of land from Frelimo [the ruling party since independence in 1975]. That time, there was plenty of space and we were few; there was room to grow maize and vegetables also. But then the war [civil war, 1976-1992] hit us all and we had to give up lots of our land. When the war was winding down, in 1989, there was a type of competition; everyone seemed to change their houses building with cement and starting erecting walls between neighbors. It was a war of walls and people no longer circulated through the household of others.

Bernardo's recollection is typical in reflecting spatial transformations in tandem with more encompassing political processes_-including gentrification. But commenting on today, he emphasizes how novel materialities and implicit moral registers of differentiation related to aesthetic forms of enclaving work to reform Maxaquene:

Now things are changing, with Top Terra Moçambique [a real-estate company] having moved in. They buy all the land and say we do not belong here; that we should move out if we cannot build big. This means all the walls we have constructed now means nothing. Nothing! They are only there to show borders between people but mean nothing when 'the big people' can look down on us from their condominiums. We have again become small, our space outside cannot be used. We have to leave here soon, we know that.

The entry of large and small agents to buy land and houses and convert these into sellable plots for development has fundamentally transformed the bairro, the relation between people, as well as widespread moral understandings and spatial imageries of material forms. Crucially, while flexibility of domestic space and household has been central to the whole trajectory of Maxaquene, as also emphasized by Bernardo, the principle has now been hardened by processes of enclaving. For one, this relates to the temporal horizon where local residents like Bernardo understand that non-fixity now means that the city will be purged of inhabitants like him; Bernardo will probably have to relocate to the margins of Maputo. The future city, one that is enclaved, thereby impedes on and fences in his present. Second, while flexibility historically meant shifting sites and sizes of plots, the erection of walls, dramatically alters relations to your neighbor. This is so as the previously social ideal of eye-level sociality reflective of the bairro's one-level housing and low or 
non-existent perimeter fencing has been exchanged for the aesthetics and realities of condominiums and verticality. Effectively, enclaving in this format perforates social and physical space.

\section{Vignette 2: Staring at the wall}

In 2019 a real estate agent, Tiago, gave author 2 and his wife a tour of a soon to be completed, mixed-use enclaved tower occupying some of the city's prime central real estate, which combines a hotel with residential apartments. The building was the result of the tortuously intertwined processes of economic accumulation and domestic and international political calculation between various state and non-state actors that is frequently known by the innocuous moniker of "SouthSouth" relations. One of the major players in Mozambican urban development is ATA Construction, who have already built over 11 major projects including gated communities, schools, malls, hotels, condominiums and mixed-use residences in Maputo and the neighbouring Matola (http://ataconstrucoes.com/). ATA Construction is connected to the Gülen movement from Turkey. After accusing the Gülenists of being behind the attempted coup of 15th of July 2016, the Turkish president Recep Tayyip Erdoğan tried to pressure the Mozambican government to cut all ties with ATA Construction and anyone else that was allied to the Gülen movement. Erdoğan has made similar moves throughout the world, but his efforts in Mozambique failed and were met with a point-blank refusal. Mozambicans active in urban planning and development told author 2 that Erdoğan than changed tact and encouraged regime aligned business interests to invest in urban development in Maputo, demonstrating the benefits of working with the Turkish state while crowding out rivals.

Political rivalry involving distant power struggles and local diplomatic alignments seems to have provided the initial impetus of investment for a large enclaved complex. While the investors and management of the complex did not broadcast their affiliation, it was not hidden either. This became clear when author 2 asked to use the restroom and was directed to an office in the back, where one wall was largely covered by a giant portrait of President Erdoğan. Distant political point scoring was not the only reason for constructing the enclaved complex. For over the past decade, Mozambique, despite a series of political and economic crises has been gearing up to be a significant exporter of natural resources, primarily LNG and coal. This enclaved complex, as with many others, was designed to accommodate the influx of expatriates drawn to Maputo to work in the natural resource industry, as well as select members of the Mozambican upper class. Tiago 
bragged that five ministers were already owned apartments there. The strategy of providing enclaved accommodation to different social, occupational or national categories of people is not new. Author 2 had just been visiting a friend in a gated community built for Italian cooperants, or political sympathetic aid workers during the socialist period. However, the marketing strategy had changed considerably from international solidarity and building socialism to security, exclusion, misleading points of law, panoramic views and high-quality German appliances.

Tiago took author 2 and his wife through two of the surprisingly cramped, not terribly impressive apartments considering a two-bedroom was going for 200,000USD and 360,000USD or more for, the far more spacious, a three-bedroom flat. Tiago spent his time repeatedly pointing their Bosch furnishings and the sales technique was high pressure, but artfully done. While doing so, Tiago was constantly engaging in phone calls of perhaps dubious province with a wide variety of foreigners who were, coincidentally, just about to buy an apartment author 2 and his wife wanted to look at. Interestingly, Tiago's performance was also interspersed with strategic falsehoods: He claimed that a foreigner could not buy an apartment in an old building as these were state patrimony, but this would not apply to newly build apartments. This is not true. The state owns the land in Mozambique, but this does not apply to apartments which can be owned by either a Mozambican or a foreigner. Tiago's selective interpretation of Mozambican land laws was soon undercut with a surprising admission, however. When author 2 asked him what the advantage of an apartment was over a house, he bluntly replied, "A house is always better" and immediately proceeded to emphasise what could be offered by, the admittedly lesser option of this building, such as the security (a reception desk, CCTV, armed response guards) and the high number of foreigners who would live along with other social notables such as the previously mentioned ministers.

In many ways the description above seems to fit the standard explanation of enclaving being an "ecology of fear" and certainly security was the buildings primary selling point, along with the exclusiveness of the neighbours. In fact, Tiago openly explained that it would be better to have one's own house with the privacy and autonomy that supposedly comes along with homeownership. In fact, it was a little surprising that such apartments would be attractive to upper echelon of Mozambican society, such as government ministers, those who could presumably afford their own home. Nor was it ever clear if such august personages ever considered residing in such a building. Author 2 later heard a rumour that they had simply appropriated entire floors as a cost of accessing 
the local market without ever moving in. However, this very contested desirability illustrates the ways in which migrating social forms both shape a local environment and are integrated into particular circumstances. As with the earlier examples of the People's Republic of China and Singapore, many different political, economic and cultural logics have become uneasily intertwined in this enclaved building. Here distant political jockeying provides the impetus of updating residential strategies for a new economic market, while offering new avenues of profit for the powerful both near and abroad. Paradoxically, an enclaved complex designed on the principles of panoptical control manages to at least partly serve the interests of multiple privileged actors, while being under the total control of none.

\section{Vignette 3: Future plans}

Author 1 recently met up with Manuel Goveia, the head of the Department of Urbanization at the Maputo Municipality, to discuss the process of making 'partial plans' (planos parciais) for those peri-urban areas where many both national and foreign investors want to build condomínios fechados (gated communities). As Goveia told author 1, in order to be able to have some kind of control over the growing and only partially legal land market, it was crucial to have some form of planning device and in this regard, the partial plans seemed like the best tool in the toolbox. The only problem being, of course, that given the weak administrative capacities on all levels, the necessary urban planning devices are still too few and badly managed. Not without a hint of frustration, Goveia acknowledged that state and municipality are often completely incapable of controlling the increasing commoditization of peri-urban land-irrespective of current land laws stipulating that all land belongs to the state and thus cannot be transacted (República de Mocambique, 2004; Tanner, 2002). 'This is really a shitty situation'. Goveia sighed and took a sip of his beer before continuing: 'We need plans! But plans don't exist!' What Goveia and his colleagues at the municipality needed was a set of planning devices, which would enable them to monitor and control ongoing construction activities, not least those of a growing number of foreign building companies seeking to invest in peri-urban property and land in order to make large-scale enclave developments. I asked Goveia if there was nothing to be done about the seemingly chaotic situation. 'Well.' Goveia looked at author 1 with a mischievous grin. 'We have actually experimented with a few things, which seem to work. It's what we call 'future plans' (planos do futuro)'. As Goveia then went on to explain in great detail, not unlike the partial plans, a 'future plan' outlines the basic parameters of a predefined urban space, such as those of a quarter 
(quarterão) in a peri-urban neighborhood. ${ }^{3}$ It thus projects the required infrastructural systems (water, sanitation and electricity, road net and parceling of individual land plots). In contrast to the partial plan, however, the future plan also includes an elaborate description of the administrative units functioning in the area, e.g. police stations, primary schools and health centers. Still, what distinguished the future plan the most was probably the fact that it would never be realized. 'This is not a plan', Goveia assured author 1. 'It is something we came up with in order to be able to manage the situation on the outskirts of the city'. Indeed, according to both Goveia and several other architects and land surveyors at the Maputo Municipality, the future plan was a device invented in order to pragmatically attempt to restrict or at least being able to influence as much as possible the activities of the growing number of construction companies eager to build huge enclave condominiums near the city center, as discussed in the second vignette. Without urban plans defining the parameters of area requested by construction companies, it was increasingly difficult for state and municipal officials to monitor and control their activities. However, with a future plan, Goveia and his colleagues could refer to the (imagined) projections and thus prevent or, at least, stall unwanted construction activities, say, by arguing that a certain area could not be parceled out for a new project given that the future plan indicated that a primary school would be build in the area in question.

At the face of it, the future plan did sound like a workable solution for the immediate problem caused by a lack of administrative resources at all levels. Being somewhat impressed by the ingenuity of the idea, author 1 therefore asked Goveia whether it had the desired effect of actually curbing investments in peri-urban land. 'Oh noooo!', Goveia laughed and shook his head. 'That is not the intention at all! Don't you get it? We want the condominios! That's the whole point! But we want to be able to drive the car, you know. Who wants to sit in the driver's seat?'

While author 1 had somewhat naïvely assumed that Goveia was describing an instrument devised entirely with the objective of getting some kind of control over a land market that was rapidly picking up pace, it was also (and perhaps predominantly so) intended as a platform for the officials to be able to continuously negotiate the terms of the investors' presence in the city. In a nutshell, the future plans were money-making machines. For, as author 1 would soon come to realize, not only

\footnotetext{
${ }^{3}$ Most urban and peri-urban neighborhoods in Maputo are divided into quarters usually comprising between 100-150 households each.
} 
were Goveia and his colleagues interested in profiting from the growing number of planned largescale building projects, the enclaved condominio was the ideal form of the city that they were envisioning. As Goveia saw it, at the same time as the many local and foreign construction consortia were building gated communities along the picturesque Costa do Sol area of Maputo, they were also giving new life to a slowly dying city.

In these three examples, enclaving is not solely an economic venture but also a series of more or less coordinated attempts to create some form of order, control and uniformity among what is often viewed by the privileged as the potentially dangerous chaos of the city. While no one can deny that it has unleashed a process of social transformation, the end result remains an open question. In Vignette 1, Bernardo feels trapped in a present that he no longer controls. Although he still lives in the peri-urban neighborhood that used to offer a necessary spatial flexibility, the transformations brought on by new real-estate companies seem to diminish Bernardo's physical and social room for maneuvre. In Vignette 2, on the other hand, local spatial plans and international diplomacy combine in unexpected ways as internal political disputes in Turkey become the catalyst for new forms of spatial segregation that transcend the confines of their own immediate materiality. A similar kind of entrepreneurial pragmatism can be detected in Vignette 3, where the head of the Department of Urbanization at Maputo Municipality tries to shape the pace of enclave urbanism through the use of fake urban plans; not because he wants to minimise real estate investments but, simply, so that he can 'sit in the driver's seat'.

In sum, what we take from these three vignettes, then is that the hierarchialized space of the enclave considered both as a migrating urban form and an aesthetic of imagination - and above imagined as large-scale real estate investments, as gated communities and as urban development respectively generates not only built forms but re-directs different and multilayered flows of desire (cf. Simone, 2019: 129). While one can interpret this desire or re-orientation outward as either reflecting capitalist forms of expulsion (Sassen, 2014) or, in more local terms, as re-affirmation of dormant yet powerful rural connections (Tvedten, 2018), the centripetal desires reflect an acute sense of verticalized enclaves (both built and imagined) as perforating local worlds and, thus, reconfiguring the distances and divisions of city through introspection into households (Vignette 1), through capitalization of political rivalries (Vignette 2) and through management of forces, which refuse to be managed (Vignette 3). 


\section{Migration of spaces and material forms in sub-Saharan Africa}

James Ferguson has described how economic investments in resource extraction across the African continent tends toward being concentrated in secured enclaves, which move capital across national borders without encompassing actual geographical spaces $(2005,2006)$. This enclaved economic model is characterized by mixed and intertwined sovereignty that operate under special legal regimes with highly unequal access to infrastructure and secured by private security forces for the economy more generally (see also Appel, 2012; Kirshner and Power, 2015). Focusing particularly on the booming oil industry, Ferguson argues that,

Usable Africa gets secured enclaves—noncontiguous 'useful' bits that are secured, policed, and, in a minimal sense, governed through private or semiprivate means. These enclaves are increasingly linked up... in transnational networks that link dispersed spaces in a selective, point-to-point fashion (2005: 380).

Without benefitting the wider society, financial investments in the oil sector are concentrated in secured enclaves that are 'ringfenced' against the real or imagined disorganization of local economies. In contrast to earlier 'socially thick' economic models, a bifurcated model is introduced, which 'hollows out' the state (Clapham, 1996), while the enclave increasingly comes to operate as a private mercantilist entrepôt that has liberated itself from the restrictions of geographical attachment:

(C)apital 'hops' over 'unusable Africa,' alighting only in mineral-rich enclaves that are starkly disconnected from their national societies. The result is not the formation of standardized national grids, but the emergence of huge areas of the continent that are effectively 'off the grid' (Ferguson 2005: 380).

As capital 'hops' over 'unusable Africa', natural resource extraction turns into a particularly efficient form of 'surgical colonialism' (Bergesen, 2008), which “involves a minimum of local disruption, making the extraction almost surgical in nature". In this regard, it is the place rather than the people that is useful and so a process of dispossession, say, in the form of land grabs or 
extensive export of hardwood, might occur without any significant involvement of local populations (Murray Li, 2010; see also Tsing, 2000). Capital is territorialized, to be sure, but within economic zones, which are organized in order to strategically reduce the possibility for mutually beneficial engagements with the local 'outside' to an absolute minimum. Crucially, however, the territorialization of capital does not imply that enclaving is fixed to a physical territory once and for all. As also convincingly argued by Ferguson, the ringfencing of investments may allow for a dynamic and hyper-flexible migration of spaces and material forms, such as when a modular form of the segregated enclave is being wedged into different physical localities across a larger region (Bunkenborg, M. Nielsen, et al 2020 (In press)).

For Mozambique, for example, Kirshner and Power argue that mining enclaves in Tete Province are reshaping both economic life and urban planning, recreating deeply exclusionary colonial models of company rule on the one hand, while drawing local elites more tightly into international networks on the other (2015: 70). Thus, Russian speculative capital fuels the construction of private cities in Ghana, Nigeria, Kenya and Zambia; Chinese imperial, extractive and infrastructural expansion animates economies and urban spaces across the continent's cities; urban real estate development is commonly used as money laundering operations for illicit accumulation. It is precisely this chameleon-like nature, we argue, its ability to combine aspirations and profound inequality, predatory neo-colonialism and new forms of social mobility, new public management and socialist authoritarianism, that make enclaving so flexible yet durable. Often it is this dual nature, both dystopic and aspiration, that makes it so resilient to widespread condemnation.

For the cities in sub-Saharan Africa, we need to cast an equally wide analytical net in order to capture the ramifications of recent economic, social and political developments. For what is unfolding in sub-Saharan cities cannot be discerned by examining only the social effects of new governmental technologies or by tracing the economic repercussions of large-scale speculative investment schemes. Rather, as we have also outlined through our discussion of the three empirical vignettes above, the dynamics, pace and tension points of many urban landscapes are gradually being recalibrated in relation to an aesthetics of imagination, which we define as enclaving.

With its preeminent place in the continent's financial infrastructure and the long history of racial segregation, culminating in the apartheid political project, Johannesburg could be taken as the 
epitome of enclaving in Africa. Martin Murray has described the ways that the, introduction of new techniques of spatial management has reshaped the urban landscape in novel and unanticipated ways, supplanting meaningful urban public space with cocooned, privatized surrogates and putting into motion entirely new dynamics of separation, fragmentation and exclusion' (2001: 8). In tracing these processes, Murray documents three major forms of enclaved communities in Johannesburg. The first is what he terms the 'Outcast Ghetto', which encompasses the abandoned and rapidly decaying inner city (ibid: 148). The inhabitants of such ghettos, such as the infamous Hillbrow, which include the poor, the forgotten, undocumented immigrants, the socially marginalized come to be the 'territorially stigmatized' other who are indiscriminately labelled as an undesirable, criminal class solely due to where they live as opposed to any action they have ever actually undertaken (ibid: 153). The second form are the upscale gated communities that have appeared at the edge of the city where affluent whites and increasing, in the post-apartheid era, well-off blacks have found refugee from the crime and decay of the city proper. The growth of gated communities has accompanied deregulation and the adoption of neo-liberal principles and 'new public management', creating comfortable, secure enclaves and eye-catching amenities for the chosen few, allowing municipal authorities and developers to claim the coveted title of 'world class' city amidst a vast sea of deprivation and neglect. Such processes are reaching their apogee with the third type of enclaved community, entirely new, private cities, such as Waterfall City on the outskirts of Johannesburg (Herbert and Murray, 2015; Murray. 2015). As Murray convincingly shows, contemporary forms of enclaving in Johannesburg are not simply capitalist means of recreating apartheid though, even if similarities abound. Instead, Johannesburg provides a productive lens through which to view the ways in which the old and the new orders are caught in an uneasy dialectic, becoming, in practice, hopelessly intertwined (ibid: 332).

As in the three vignettes above, enclaving finds its most overt physical configuration in the segregated urban enclave, such as the gated community or walled off tower, but, as we venture to speculate, it might be that enclaving finds its optimal manifestation as a conduit of urban imageries, which - by themselves - are never equal to their own material realization. Here we might again return of Manuel Goveia, the official at Maputo Municipality described in the Vignette 3, or the various rivalries that fuelled the enclaved tower in vignette 2 , as, ways to engage with the city without necessarily being able to control the processes of its implementation while the benefits are 
largely monopolised by the powerful, leaving irregular payoffs and desultory compensation for those most affected.

\section{Conclusion}

In contrast to processes of physical segregation in Euro-American cities, what we consider as particularly salient about enclaving in sub-Saharan Africa is precisely the activation and operationalization even of an aesthetics of imagination that is not tied to an immediate material manifestation (cf. Nielsen and Pedersen, 2015). So, for instance, Bernardo, the unfortunate Maxaquene resident described in the first vignette, has essentially reimagined the city as an uninhabitable wasteland (pace Simone, 2019) because of the massive and violent interventions in the area occurring through acts of enclaving. In fact, what might give to enclaving its social efficacy is precisely the hyper-flexible malleability of a spatial form without losing its core qualities. This leads us to suggest that as an aesthetics of imagination, enclaving migrates between and across different physical locations. To be sure, the physical manifestation of enclaving, such as the gated community, is a monumental affirmation of a particular and very visible form of detachment but it is by way of its nomadic movements across the city that it comes to have deeper and also more complex and heterogeneous effects. The four protagonists of the vignettes above are all moving with the ebbs and flows of enclaving as it makes its way across the city's spaces. For Bernardo, Tiago, Selma and Goveia, enclaving is not simply an aesthetic figuration or idealization of the city. Rather, it is the sense of an almost rhythmic pulse that seems to set in motion the spaces in which these people live and connects different territories, localities and positions without any coherent or easily decipherable systematicity emerging. And that is, paradoxically, one of the key characteristics of what enclaving is. As an aesthetics of imagination, enclaving gives concreteness, solidity and magnitude to the city but in ways that are not necessarily trapped by its physicality.

Urban landscapes in sub-Saharan Africa thereby powerfully and dynamically actualize lines of separation, which stretch out into a wider multi-layered meshwork of political divisions, economic fissures and social detachments. While they do offer the possibility of the kinds of 'oppressive private socialism' (Soja, 2000:315) that have reconfigured the dynamics of many Euro-American cities, that is not the main locus of their operations. Instead, through a wide and ill-coordinated array of spatial technologies, investment strategies, governmental regulations and intensified movements of persons, things and ideas, certain kinds of divisions come to assert themselves with 
acute determination and force. It can therefore be expected that the physical manifestation of a separation (say, a wall) will activate different registers of detachment than those that initially prompted the building project itself. Think again of the untenable situation that Bernardo finds himself in. As much as he is worried about the magnitude of the building projects, it is the disruptions of the existing territory - the rescaling of the area (Tsing 2005) and the consequential loss of visibility, so to speak, that is the main concern here.

With the notion of 'enclaving', then, we wish to trace the particular meshwork of separations, fissures and disconnections of which the detached sub-Saharan African urban enclave is an optimal physical manifestation but one that cannot contain the production of tropes and ideas of segregation deriving from that particular built form. While there is no singular logic to how the many segregated urban spaces are being built in cities across the continent, we argue that they do nevertheless reflect a certain 'aesthetics of imagination', which can be examined empirically and submitted to historical analysis and cross-cultural comparison. And while enclaving does carry grand promises of monumental urbanism, as an aesthetics of imagination it is itself more like a set of 'entangled relations that endow objectives with seemingly stable and linear boundaries' (Roberts 2017: 595). Indeed, considered as an aesthetics of imagination, enclaving is a loosely structured orientation to urban spaces based on separation, which stretches from subjective and collective forms of social differentiation to overt material manifestations. It is both the enactment of a desire for privilege, the physical or ideational representation of the privilege itself and the tension that exists between the two. Rather than stemming from specific and clearly defined socio-economic divides, enclaving can be considered as a fluid and transformative form of detachment and separation that generates new forms of urban positions, strategies and ideals. As noted in the second vignette, such strategies can loosely serve a variety of interests, while not be under the total control of any one set of actors. In many instances, enclaving offers itself as guarantor of both spatial and temporal security by physically or imaginatively stabilizing the relationship of person and space in the form of a predictable future. As such, enclaving implies not just the spatial representation of an explicit ideal, a status or a sense of belonging but also an active intervention in the ambiguous space between the known and the unknown, the certain and the uncertain.

The existing body of work on enclaving in Euro-America and sub-Saharan Africa has generated crucial insights about the socio-political and economic inequalities that are both caused by and have 
fed into the making of physical urban divides. Having taken cues from these studies, in this article we have intended to go beyond the localized spatial fixity of enclaving that is an integral part of these analyses. Instead, and based on material from Africa in general and Maputo in particular as well as relevant studies of historical and contemporary forms of enclaving from Euro-America, we have suggested that it operates most optimally as an aesthetics of imagination leading to what might best be described as the migration of spaces and material forms.

\section{Bibliography}

Adams, RE (2014) The Burden of the Present: On the Concept of Urbanisation. Society and Space 11.

Appel H (2012) Walls and white elephants: Oil extraction, responsibility, and infrastructural violence in Equatorial Guinea. Ethnography 13(4): 439-65.

Balasopoulos A (2013) Pigs in heaven? Utopia, animality and Plato’s Huopolis. In: Silva JB (ed) The Epistemology of Utopia. Rhetoric, Theory, and Imagination. Cambridge: Cambridge Scholars Publishing, pp. 8-27.

Balasopoulos A (2014a) Celestial cities and rationalist utopias. In: McNamara KR (ed) The Cambridge Companion to the City in Literature. Cambridge: Cambridge University Press, pp. 17-30.

Balasopoulos A (2014b) Factories, utopias, decoration and upholstery: On utopia, modernism, and everyday life. Utopian Studies 25(2): 268-298.

Bergesen A (2008) The new surgical colonialism: China, Africa, and oil. Paper presented at the American Sociological Association Annual Meeting. Boston, 31 July.

Bertelsen BE, I Tvedten, and S Roque (2014) Engaging, transcending and subverting dichotomies: Discursive dynamics of Maputo's urban space. Urban Studies 51(13): 2752-2769.

Blakely E and MMG Snyder (1997) Fortress America: Gated Communities in the United States. Washington, DC: Brookings Institute.

Boeck, Fd (2011). “Inhabiting Ocular Ground: Kinshasa's Future in the Light of Congo's Spectral Urban Politics." Cultural Anthropology 26(2): 263-286.

Boeck Fd and M-F Plissart (2014 [2004]) Kinshasa. Tales of the Invisible City Leuven: Leuven University Press. 
Braun G, F Hogenberg and S Füssel (2015 [1572-1617]) Civitates orbis terrarum = Cities of the world : 363 engravings revolutionize the view of the world : complete edition of the colour plates of 1572-1617. Cologne: Taschen.

Breitung W (2012) Enclave urbanism in China: Attitudes towards gated communities in Guangzhou. Urban Geography 33(2): 276-294.

Bunkenborg, M., M. Nielsen, et al. (2020 (In press)). Collaborative Damage. An Experimental Ethnography of Chinese Gobalization. Ithaca \& London, Cornell University Press.

Buxton N and B Hayes, eds (2016) The Secure and the Dispossessed: How the Military and Corporations are Shaping a Climate-Changed World. London: Pluto Press.

Caldeira TPR (1996) Fortified enclaves: The new urban segregation. Public Culture 8: 303-328.

Caldeira TPR (1999) Fortified enclaves. The new urban segregation. In: SM Low Theorizing the City. New Brunswick, NJ: Rutgers University Press, pp. 83-107.

Caldeira TPR (2000) City of Walls. Crime, Segregation, and Citizenship in São Paulo. Berkeley and Los Angeles, CA: University of California Press.

Campanella T (1981 [1623]). La Città del Sole: Dialogo Poetio / The City of the Sun: A Poetical Dialogue. Berkeley, CA: University of California Press.

Cinar, A. and T. Bender, (Eds.) (2007). Urban Imaginaries. Locating the Modern City. Minneapolis, University of Minnesota Press.

Cirolia LR (2013) (W)Escaping the challenges of the city: A critique of Cape Town's proposed satellite town. Urban Forum 25(3): 295-312.

Clapham C (1996) Africa and the International System: The Politics of State Survival. New York: Cambridge University Press.

Comaroff J and JL Comaroff (2017) The Truth about Crime: Sovereignty, Knowledge, Social Order. Johannesburg: Wits University Press.

Davis M (1992) City of Quartz: Excavating the Future in Los Angeles. London: Verso.

Davis M (1998) Ecology of Fear: Los Angeles and the Imagination of Disaster. New York: Metropolitan Books-Henry Holt.

Delft Architectural Studies on Housing DASH (2011) The Urban Enclave - De stadsenclave. Vol. 5. Delft: Nai Publishers.

Dinerman A (2006) Revolution, Counter-Revolution and Revisionism in Postcolonial Africa: The case of Mozambique, 1975-1994. Oxon: Routledge. 
Eaton R (2002) Ideal Cities: Utopianism and the (Un)Built Environment. London: Thames and Hudson.

Ferguson J (2005) Seeing like an oil company: Space, security, and global capital in neoliberal Africa. American Anthropologist 107(3): 377-382.

Ferguson J (2006) Global Shadows: Africa in the Neoliberal World Order. Durham, NC:

Duke University Press.

Glück Z (2017) Security urbanism and the counterterror state in Kenya. Anthropological Theory 17(3): 297-321. Doi: 10.1177/1463499617729295.

Graham S (2016) Vertical. The City from Satellites to Bunkers. London: Verso.

Graham S and S Marvin (2001). Splintering Urbanism: Network Infrastructures, Technological Mobilities and the Urban Condition. London: Routledge

Hanlon, J (2016) Following the donor-designed path to Mozambique’s US\$2.2 billion secret debt deal. Third World Quarterly: 1-18.

Harvey D (1973) Social Justice and the City. London: Edward Arnold

Harvey D (2000) Spaces of Hope. Edinburgh: Edinburgh University Press.

Herbert C and M Murray (2015) Building from scratch: New cities, privatized urbanism and the spatial restructuring of Johannesburg after Apartheid. The International Journal of Urban and Regional Research 39(3): 471-493.

Holston J (1989) The Modernist City: An Anthropological Critique of Brasília.

Chicago: University of Chicago Press.

Kirshner J and M Powers (2015) Mining and extractive urbanism: Postdevelopment in a Mozambican boomtown. Geoforum 61: 67-78.

Knox PL (2008) Metroburbia, USA. New Brunswick, NJ: Rutgers University Press.

Kuldova T and MA Varghese, eds (2017) Urban Utopias. Excess and Expulsion in Neoliberal South Asia. New York: Palgrave Macmillan.

Le Corbusier (1986 [1931]) Towards a New Architecture. New York: Dover Books.

Lees L, HB Shin and E López-Morales (2016) Planetary Gentrification. Cambridge: Polity Press.

Liao, K, R Wehrhahn, and W Breitung (2019). Urban planners and the production of gated communities in China: A structure-agency approach. Urban Studies 56(13): 26352653.

Low S (2003) Behind the Gates. New York: Routledge. 
MacKenzie E (1994) Privatopia: Homeowner Associations and the Rise of Residential Private Government. New Haven, CT: Yale University Press.

Maskens M and RLB Blanes (2018) Introduction. Utopian encounters. Anthropologies of empirical utopias. In: M Maskens and RLB Blanes (eds)Utopian Encounters. Anthropologies of Empirical Utopias. Oxford: Peter Lang, pp. ix-xxxvii

Morton, D (2019). Age of Concrete. Housing and the Shape of Aspiration in the Capital of Mozambique. Athens, $\mathrm{OH}$ : Ohio University Press.

Murray Li T (2010) To make live or let die? Rural dispossession and the protection of surplus populations.In: N Castree et al. (eds) The Point is to Change It: Geographies of Hope and Survival in an Age of Crisis. Antipode Supplement. Chichester, Wiley-Blackwell, pp. 66-93. Murray MJ (2011) City of Extremes: The Spatial Politics of Johannesburg. Durham, NC:

Duke University Press.

Murray MJ (2013) 'City doubles': Re-urbanism in Africa. Paper presented at the ECAS 2013: Multi-polar Urban Spaces in Africa: Everyday Dynamics, Creativity and Change. Lisbon, 27-29 July.

Murray MJ (2015) Waterfall City (Johannesburg): Privatized urbanism in extremis.

Environment and Planning A 47: 503-520.

Murray, MJ (2017). The Urbanism of Exception. The Dynamics of Global City Building in the Twenty-First Century. Cambridge, Cambridge University Press.

Nielsen M and MA Pedersen (2015) Infrastructural Imaginaries: Collapsed Futures in Mozambique and Mongolia. In: M Harris and N Rapport (eds.) Reflections on Imagination. Human Capacity and Ethnographic Method. Farnham: Ashgate: pp. 237-262.

Pow C-P (2009) Public intervention, private aspiration: Gated communities and the condominisation of the housing landscape in Singapore. Asia Pacific Viewpoint 50 (2): 215227.

Price B (2016 [2002]). Francis Bacon's New Atlantis. Manchester: Manchester University Press. Ong, A. (2011). Worlding Cities, or the Art of Being Global in: A. Roy and A. Ong, (Eds.): Worlding Cities. Asian Experiments and the Art of Being Global Malden, Ma., WileyBlackwell: pp. 1-26.

Quayson A (2014) Oxford Street, Accra: City life and the itineraries of transnationalism. Durham and London: Duke University Press.

República de Mocambique (2004). Land Law Legislation. Maputo: MozLegal. 
Roberts, EFS (2017) What Gets Inside: Violent Entanglements and Toxic Boundaries in Mexico City. Cultural Anthropology 32(4): 592-619.

Sassen S (2014) Expulsions. Brutality and Complexity in the Global Economy. Cambridge, MA: Harvard University Press.

Schuermans N (2016) Enclave urbanism as telescopic urbanism? Encounters of middle class whites in Cape Town. Cities 59: 183-192. doi: https://doi.org/10.1016/j.cities.2016.02.002.

Seligman AB (1989) Order and Transcendence: The role of utopias and the dynamics of civilizations. Leiden: Brill.

Sidaway JD (2007) Enclave space: a new metageography of development? Area 39(3): 331339.

Simone A (2019). Improvised Lives. Rhythms of Endurance in an Urban South.

Cambridge: Polity Press.

Simone A and E Pieterse (2017) New Urban Worlds. Inhabiting Dissonant Times.

Cambridge: Polity Press.

Smith N, and P Walters (2018). Desire lines and defensive architecture in modern urban environments. Urban Studies 55(13): 2980-2995.

Soja E (2000) Postmetropolis: Critical Studies of Cities and Regions. Oxford: Blackwell.

Sorkin M (1992) Variations on a Theme Park: The New American City and the End of Public Space. New York: Hill and Wang.

Ssorin-Chaikov N (2018) Hybrid peace: Ethnographies of war. Annual Review of Anthropology 47: 251-262.

Sumich J (2018) The Middle Class in Mozambique: History, State and Transformation in Southern Africa. Cambridge: Cambridge University Press.

Strathern M (2000) Environments within: An ethnographic commentary on scale. In: K Flint and H Morphy (eds) Culture, Landscape, and the Environment: The Linacre Lectures 1997. Oxford: Oxford University Press: pp. 44-71.

Tanner C (2002) Law-Making in an African Context: The 1997 Mozambican Land Law. Rome: FAO Legal Office.

Thoreau HD (1992 [1910]) Walden. Or, Life in the Woods. New York: Everyman's library. Tsing AL (2000) Inside the economy of appearances. Public Culture 12(1): 155-144. Tsing AL (2005). Friction. An Ethnography of Global Connection. Princeton: Princeton University Press. 
Tvedten I (2018) 'It's All about Money: Urban-rural spaces and relations in Maputo,

Mozambique. Canadian Journal of African Studies / Revue canadienne des études africaines 52(1): 37-52.

van den Heuvel D (2011) Piet Blom's domesticated superstrucures.In: by Delft architectural studies on housing DASH (ed) The Urban Enclave - De stadsenclave. Delft: NAi Publishers, pp. 56-70.

West HG (2009) From socialist chiefs to postsocialist cadres. Neotraditional authority in neoliberal Mozambique. In: HG West and P Raman (eds) Enduring Socialism. Explorations of Revolution and Transformation, Restoration and Continuation. . New York and Oxford: Berghahn Books, pp. 29-43.

Wissink B et al (2012) Introduction. Living in Chinese enclave cities. Urban Geography 33(2): 161-166.

Zhang L (2010) In Search of Paradise: Middle Class Living in a Chinese Metropolis. Ithaca, NY: Cornell University Press.

Zhao T (2006) Rethinking empire from a Chinese concept 'All-under-Heaven' (Tian-xia). Social Identities 12(1): 29-41. 